\section{Article}

ZOBIOLE, L.H.S. ${ }^{1 *}$

GAST, R. ${ }^{2}$

MASTERS, R.A. ${ }^{2}$

PEREIRA, G.R. ${ }^{1}$

RUBIN, R. ${ }^{1}$

\title{
Pyroxsulam: Sulfonamide Herbicide for Weed CONTROL IN WhEAT IN BRAZIL
}

\section{Pyroxsulam: Sulfonamida para o Controle de Plantas Daninhas na Cultura do Trigo no Brasil}

\begin{abstract}
Few herbicides are currently registered in Brazil for weed control in wheat. The objective of this research was to determine the wheat crop selectivity and the response of Lolium multiflorum to pyroxsulam. Field experiments were conducted at two locations in Paraná, Brazil. At the proposed commercial rates of 15 and $18 \mathrm{~g}$ a.i. ha ${ }^{-1}$ pyroxsulam did not cause visual injury above $10 \%$ in wheat. Pyroxsulam caused $>10 \%$ injury in wheat at one location (Cascavel) when applied at $21,30,36$ and $42 \mathrm{~g}$ a.i. ha ${ }^{-1}$; however, the crop fully recovered from the injury by 28 days after application and did not have an adverse effect on wheat grain yield, regardless of the rate applied. Pyroxsulam applied at 15 or $18 \mathrm{~g}$ a.i. ha ${ }^{-1}$ provided excellent control ( $>85 \%)$ of Lolium multiflorum in both trials.
\end{abstract}

Keywords: visual injury, Triticum spp., ALS-inhibiting herbicides, systemic herbicide, Lolium multiflorum.

RESUMO - Atualmente, no Brasil, existem poucos herbicidas registrados para a cultura do trigo com a finalidade de controle de plantas daninhas. O objetivo deste trabalho foi determinar a seletividade do pyroxsulam à cultura do trigo e o controle de Lolium multiflorum. Foram conduzidos dois experimentos em campo, em diferentes localidades do Paraná. Nas doses de registro comercial de 15 e $18 \mathrm{~g}$ i.a. ha ${ }^{-1}$, pyroxsulam não causou injúria visual superior a $10 \%$ à cultura do trigo. Quando aumentada a dose do produto para 21 a $42 \mathrm{~g}$ i.a. ha-1, em Cascavel, ocorreu injúria superior a 10\%; contudo, houve recuperação total dos sintomas aos 28 dias após a aplicação. O rendimento de grão de trigo não foi afetado em nenhuma das doses estudadas. O herbicida pyroxsulam aplicado nas doses de 15 ou $18 \mathrm{~g}$ i.a. $\mathrm{h}^{-1}$ proporcionou controle superior a $85 \%$ em Lolium multiflorum nos dois experimentos.

Palavras-chave: injúria visual, Triticum spp., herbicidas inibidores da ALS, herbicidas sistêmicos, Lolium multiflorum.

\section{INTRODUCTION}

Wheat is the most widely grown crop in the world and provides $20 \%$ of daily protein and of food calories for 4.5 billion people (Nigro et al., 2014). In Brazil, wheat is cultivated in the south, southeast and mid-west regions. In approximately 2.12 million hectares, 6.76 million $\mathrm{kg}$ are produced in Brazil, with an average yield of $2,853 \mathrm{~kg} \mathrm{ha}^{-1}$. Annual wheat consumption in Brazil is

1 Dow AgroSciences Industrial Ltda. Av. Nações Unidas, 14.171. São Paulo, São Paulo, Brasil; ${ }^{2}$ Dow AgroSciences LLC. 9330, Zionsville Rd, Indianapolis-IN, USA. 
around 11.8 million $\mathrm{kg}$, and consumption per capita is about $59 \mathrm{~kg} \mathrm{ha}^{-1}$ (Conab, 2017). However, weed interference can cause yield losses in cereal crops of up to $80 \%$, depending on infestation level (Izquierdo et al., 2003). The main grass and broadleaf weeds infesting wheat in Brazil are Lolium multiflorum, Avena sativa, Polygonum convolvulus and Raphanus raphanistrum. In addition, the presence of Conyza sp. has recently increased in wheat fields in Paraná and Rio Grande do Sul. In many areas in the South of Brazil, Conyza sp. and Lolium multiflorum have been determined to be resistant to glyphosate (Roman et al., 2004; Vargas et al., 2007).

Herbicides are the most common tool used by growers to control weeds in wheat crops (Montazeri et al., 2005). In Brazil, there are only 5 herbicide molecules $(2,4-\mathrm{D}$, Metsulfuron, Bentazone, Clodinafop, and Iodosulfuron) registered for use in wheat (SEAB, 2015). Pyroxsulam [N-(5,7-dimethoxy[1,2,4]triazolo[1,5-a]pyrimidin-2-yl)-2-methoxy-4(trifluoromethyl)pyridine-3-sulfonamide] is a triazolopyrimidine sulfonamide ALS-inhibiting herbicide that provides selective post-emergence control of grass and broadleaf weeds in certain cereals. Pyroxsulam is a systemic herbicide applied in cereals at early post-emergence. When combined with the safener cloquintocet-mexyl in commercial herbicide product formulations, pyroxsulam is selective to winter and spring wheat varieties (including durum wheat), winter rye, and winter triticale when applied in early autumn through mid-spring (Deboer et al., 2006). Cloquintocet-mexyl enables cereals to metabolize pyroxsulam more rapidly.

The objective of this study was to determine the effect of pyroxsulam applied with cloquintocetmexyl on weed control, wheat injury and yield.

\section{MATERIAL E METHODS}

Experiments were installed at two locations in Braganey and Cascavel, in Paraná-Brazil, in June 2011. The experiments were designed as randomized complete blocks with four replications. Plot sizes were $10 \times 5 \mathrm{~m}$. The chemical analysis of the soil in Cascavel had the following characteristics: $\mathrm{pH}\left(\mathrm{CaCl}_{2}\right)=5.3$; organic matter $\left(\mathrm{g} \mathrm{dm}^{-3}\right)=9.5 ; \mathrm{P}\left(\mathrm{mg} \mathrm{dm}^{-3}\right)=17 ; \mathrm{H}+\mathrm{Al}, \mathrm{K}, \mathrm{Ca}, \mathrm{Mg}$, SB and CTC $\left(\mathrm{cmol}_{c} \mathrm{dm}^{-3}\right)=3.42 ; 0.16 ; 1.88 ; 0.41 ; 2.45$ and 5.87 , respectively; and V\% $=41.73$, while textural composition of soil was $15.4 \%$ of sand, $14.3 \%$ of silt and $70.3 \%$ of clay. In Braganey, the soil chemical analysis was: $\mathrm{pH}\left(\mathrm{CaCl}_{2}\right)=5.9$; organic matter $\left(\mathrm{g} \mathrm{dm}^{-3}\right)=10.0 ; \mathrm{P}\left(\mathrm{mg} \mathrm{dm}^{-3}\right)=51$; $\mathrm{H}+\mathrm{Al}, \mathrm{K}, \mathrm{Ca}, \mathrm{Mg}, \mathrm{SB}$ and CTC $\left(\mathrm{cmol}_{\mathrm{c}} \mathrm{dm}^{-3}\right)=2.95 ; 0.84 ; 6.5 ; 2.96 ; 6.25$ and 9.2 , respectively; and $\mathrm{V} \%=67.93$, while textural composition of soil was $12 \%$ sand, $22 \%$ silt and $66 \%$ of clay.

A total of $300 \mathrm{~kg} \mathrm{ha}^{-1}$ of 10-20-20 (NPK) was incorporated into the soil on the day of planting. The wheat crop was planted in Braganey on June 10, 2011 and in Cascavel, on June 23, 2011. Emergence usually occurred at 10 days after planting. Row spacing was $17 \mathrm{~cm}$, planting depth was $5 \mathrm{~cm}$, and seeding rate was 2.000 .000 seeds ha $^{-1}$. Prior to herbicide application, the weed populations of Lolium multiflorum (LOLMU) had an average of 110 plants $\mathrm{m}^{2}$ on the Cascavel site and 60 plants $\mathrm{m}^{2}$ on the the Braganey site. In both locations, Lolium multiflorum plants were at 2-3 tillers growth stage.

A $45 \mathrm{~g}$ a.i. $\mathrm{L}^{-1}$ oil dispersion (OD) formulation of pyroxsulam, including cloquintocet mexyl safener, was used for these experiments. Pyroxsulam was applied at $(15,18,21,30,36$ and $42 \mathrm{~g}$ a.i. ha-1) with $0.5 \mathrm{~L} \mathrm{ha}^{-1}$ of Vegetable Oil (Veget Oil). The standard product was Iodosulfuron WG $\left(50 \mathrm{~kg}^{-1}\right)$, applied at $5 \mathrm{~g}$ a.i. ha-1 along with $0.5 \mathrm{~L} \mathrm{ha}^{-1}$ of sodium lauryl ether sulfate (Hoefix). In both trials, the untreated check was included.

Herbicide applications occurred on August 25, 2011 in Cascavel and on August 18, 2011 in Braganey, using a $\mathrm{CO}_{2}$-pressurized backpack sprayer delivering $150 \mathrm{~L} \mathrm{ha}^{-1}$ spray volume with a 3.0 meter boom width and 6 nozzle tips DG110015VS. On both sites, at the time of application, wheat was at tillering stage, growth stage at 2.3, according to the Feeks scale (Large, 1954) within the critical period of interference of 60 days proposed by Villegas et al. (2004). The weather conditions at application were temperature at $29{ }^{\circ} \mathrm{C}, 55 \%$ relative humidity, and $0.4 \mathrm{~km} \mathrm{~h}^{-1}$ wind speed on the Cascavel site and temperature at $27{ }^{\circ} \mathrm{C}, 59 \%$ relative humidly, and $0.1 \mathrm{~km} \mathrm{~h}^{-1}$ wind speed on the Braganey location. 
Assessments for crop selectivity and weed control were carried out at 7, 14, 28 and 45 days after herbicide application, using a visual scale 0-100\%, in which $0 \%$ means no symptoms and $100 \%$ means complete plant death (SBCPD, 1995). Crop yield was determined by manually harvesting all wheat plants present in the 20 central rows by four meters long, in each plot. The grain from each plot were weighed. Grain moisture was corrected to $13 \%$ for all plots. Data were subjected to one-way ANOVA and Tukey's test at $(\mathrm{p}<0.10)$ for mean separation in use.

\section{RESULTS AND DISCUSSION}

Control of Lolium multiflorum with pyroxsulam at 15 and $18 \mathrm{~g}$ a.i. ha ${ }^{-1}$ was not acceptable: at less than 80\%, 28 days after application (DAA) in Cascavel, compared to Braganey in the same period of time (Table 1). The delay in control in Cascavel might have been due to high weed density (110 plants $\mathrm{m}^{-2}$ ), almost twice as much as at the Braganey location (60 plants $\left.\mathrm{m}^{-2}\right)$, although at 45 days after application, the control was the same for both locations (Table 2). Previous research has shown that when the initial population is low, crop competition enables faster weed control (Buhler, 1999).

According to Devine et al. (1992), ALS-inhibiting herbicides are particularly slow acting when compared to other herbicide modes of action. Herbicidal symptomology often develops very slowly

Table 1 - Visual control of Lolium multiflorum by Pyroxsulam Cascavel/PR/Brazil, 2011

\begin{tabular}{|c|c|c|c|c|c|}
\hline \multirow{2}{*}{ Name of treatment } & \multirow{2}{*}{$\begin{array}{c}\text { Rate } \\
\left(\mathrm{g}^{\text {a.i. }} \mathrm{ha}^{-1}\right)\end{array}$} & \multicolumn{4}{|c|}{$\%$ Control } \\
\hline & & $7 \mathrm{DAA}$ & $14 \mathrm{DAA}$ & $28 \mathrm{DAA}$ & $45 \mathrm{DAA}$ \\
\hline Pyroxsulam $^{(1)}$ & 15 & $0.0 \mathrm{a}$ & $20.0 \mathrm{c}$ & $63.0 \mathrm{c}$ & $92.0 \mathrm{a}$ \\
\hline Pyroxsulam & 18 & $0.0 \mathrm{a}$ & $26.0 \mathrm{c}$ & $68.0 \mathrm{bc}$ & $91.0 \mathrm{a}$ \\
\hline Pyroxsulam & 21 & $0.0 \mathrm{a}$ & $27.0 \mathrm{bc}$ & $68.0 \mathrm{bc}$ & $91.0 \mathrm{a}$ \\
\hline Pyroxsulam & 30 & $0.0 \mathrm{a}$ & $43.0 \mathrm{ab}$ & $72.0 \mathrm{~b}$ & $93.0 \mathrm{a}$ \\
\hline Pyroxsulam & 36 & $0.0 \mathrm{a}$ & $45.0 \mathrm{a}$ & $82.0 \mathrm{a}$ & $95.0 \mathrm{a}$ \\
\hline Pyroxsulam & 42 & $0.0 \mathrm{a}$ & $52.0 \mathrm{a}$ & $85.0 \mathrm{a}$ & $98.0 \mathrm{a}$ \\
\hline Iodosulfuron $^{(2)}$ & 5 & $0.0 \mathrm{a}$ & $27.0 \mathrm{bc}$ & $73.0 \mathrm{~b}$ & $91.0 \mathrm{a}$ \\
\hline Untreated & & $0.0 \mathrm{a}$ & $0.0 \mathrm{~d}$ & $0.0 \mathrm{~d}$ & $0.0 \mathrm{~d}$ \\
\hline Tukey's HSD ( $p=0.10)$ & & 0 & 17.1 & 8.2 & 8.3 \\
\hline Standard Deviation & & 0 & 8.0 & 3.9 & 3.9 \\
\hline $\mathrm{VC}$ & & 0 & 26.5 & 6.0 & 4.8 \\
\hline
\end{tabular}

(1) Included Vegetable Oil at $0.5 \mathrm{~L} \mathrm{ha}^{-1}$; ${ }^{(2)}$ Included Hoefix at $0.5 \mathrm{~L} \mathrm{ha}^{-1}$. Values (mean \pm SE) followed by different letters are significantly $(\mathrm{p} \leq 0.10)$ different.

Table 2 - Visual control of Lolium multiflorum by Pyroxsulam Braganey/PR/Brazil, 2011

\begin{tabular}{|c|c|c|c|c|c|}
\hline \multirow{2}{*}{ Name of treatment } & \multirow{2}{*}{$\begin{array}{c}\text { Rate } \\
\left(\mathrm{g} \mathrm{a} \text { a.i. } \mathrm{ha}^{-1}\right)\end{array}$} & \multicolumn{4}{|c|}{$\%$ Control } \\
\hline & & 7 DAA & $14 \mathrm{DAA}$ & $28 \mathrm{DAA}$ & 45 DAA \\
\hline Pyroxsulam & 15 & $0.0 \mathrm{~b}$ & $45.0 \mathrm{~b}$ & $80.0 \mathrm{ab}$ & $84.0 \mathrm{bc}$ \\
\hline Pyroxsulam & 18 & $2.0 \mathrm{~b}$ & $48.0 \mathrm{ab}$ & $82.0 \mathrm{a}$ & $90.0 \mathrm{ab}$ \\
\hline Pyroxsulam & 21 & $3.0 \mathrm{~b}$ & $52.0 \mathrm{ab}$ & $81.0 \mathrm{a}$ & $89.0 \mathrm{ab}$ \\
\hline Pyroxsulam & 30 & $4.0 \mathrm{ab}$ & $50.0 \mathrm{ab}$ & $86.0 \mathrm{a}$ & $95.0 \mathrm{ab}$ \\
\hline Pyroxsulam & 36 & $5.0 \mathrm{ab}$ & $56.0 \mathrm{ab}$ & $90.0 \mathrm{a}$ & $98.0 \mathrm{a}$ \\
\hline Pyroxsulam & 42 & $10.0 \mathrm{a}$ & $68.0 \mathrm{a}$ & $92.0 \mathrm{a}$ & $98.0 \mathrm{a}$ \\
\hline Hussar & 5 & $1.0 \mathrm{~b}$ & $42.0 \mathrm{~b}$ & $67.0 \mathrm{~b}$ & $76.0 \mathrm{c}$ \\
\hline Iodosulfuron & & $0.0 \mathrm{~b}$ & $0.0 \mathrm{c}$ & $0.0 \mathrm{c}$ & $0.0 \mathrm{~d}$ \\
\hline Tukey's HSD $(\mathrm{p}=0.10)$ & & 6.7 & 23.5 & 13.2 & 13.0 \\
\hline Standard Deviation & & 3.0 & 10.6 & 5.9 & 5.9 \\
\hline $\mathrm{VC}$ & & 9.3 & 21.8 & 8.0 & 7.2 \\
\hline
\end{tabular}

Values (mean $\pm \mathrm{SE}$ ) followed by different letters are significantly $(\mathrm{P} \leq 0.10)$ different. 
and several weeks or more are required to achieve maximum efficacy. In addition, the results from these two trials are consistent with the findings of Geier et al. (2011), whose study also found that control is slow in the first weeks after application. Acceptable control is considered to be above $80 \%$, because at this level of control, wheat can grow completely and better compete with weeds. At 45 DAA at both locations, pyroxsulam at 15, 18, 21, 30, 36 and $42 \mathrm{~g}$ a.i. ha-1, provided acceptable control of Lolium multiflorum. The standard Iodosulfuron treatment at $5 \mathrm{~g}$ a.i. ha ${ }^{-1}$ provided control similar to pyroxsulam 45 DAA at the Cascavel trial location. However, there was significantly less control at the Braganey location compared to pyroxsulam at $18 \mathrm{~g}$ a.i. ha ${ }^{-1}$ or greater.

Uptake, translocation, and metabolism of pyroxsulam and cloquintocet-mexyl in wheat and blackgrass (Alopecurus myosuroides) showed that the selectivity of wheat relative to blackgrass for pyroxsulam was related primarily to a difference in the rate of metabolism and the generation of a metabolite that was herbicidally inactive to the plant. Cloquintocet-mexyl increased the rate of pyroxsulam hydroxylation in wheat while having an adverse effect on blackgrass, thus improving the selectivity differential in a crop situation (Deboer et al., 2006). The $45 \mathrm{~g}$ a.i. $\mathrm{L}^{-1} \mathrm{OD}$ formulation contains 1:2 ratio of pyroxsulam to cloquintocet mexyl, which has been shown to be an adequate amount of safener for wheat grown in the southern hemisphere (Dow Agrosciences, 2007).

Pyroxsulam at 15 to $18 \mathrm{~g}$ i.a. ha ${ }^{-1}$ did not cause observable injury symptoms at any assessment time at the Braganey trial (Tables 3 and 4). However, at the Cascavel location, pyroxsulam caused

Table 3 - Visual injury on Triticum aestivum by Pyroxsulam, Cascavel/PR/Brazil, 2011

\begin{tabular}{|c|c|c|c|c|c|}
\hline \multirow{2}{*}{ Name of treatment } & \multirow{2}{*}{$\begin{array}{c}\text { Rate } \\
\left(\mathrm{g} \text { a.i. } \mathrm{ha}^{-1}\right)\end{array}$} & \multicolumn{4}{|c|}{$\%$ Control } \\
\hline & & 7 DAA & 14 DAA & 28 DAA & $45 \mathrm{DAA}$ \\
\hline Pyroxsulam & 15 & $0.0 \mathrm{a}$ & $6.0 \mathrm{cde}$ & $0.0 \mathrm{~b}$ & $0.0 \mathrm{a}$ \\
\hline Pyroxsulam & 18 & $0.0 \mathrm{a}$ & $8.0 \mathrm{~cd}$ & $0.0 \mathrm{~b}$ & $0.0 \mathrm{a}$ \\
\hline Pyroxsulam & 21 & $0.0 \mathrm{a}$ & $10.0 \mathrm{bc}$ & $0.0 \mathrm{~b}$ & $0.0 \mathrm{a}$ \\
\hline Pyroxsulam & 30 & $0.0 \mathrm{a}$ & $13.0 \mathrm{bc}$ & $0.0 \mathrm{~b}$ & $0.0 \mathrm{a}$ \\
\hline Pyroxsulam & 36 & $0.0 \mathrm{a}$ & $16.0 \mathrm{~b}$ & $0.0 \mathrm{~b}$ & $0.0 \mathrm{a}$ \\
\hline Pyroxsulam & 42 & $0.0 \mathrm{a}$ & $28.0 \mathrm{a}$ & $5.0 \mathrm{a}$ & $0.0 \mathrm{a}$ \\
\hline Iodosulfuron & 5 & $0.0 \mathrm{a}$ & $1.0 \mathrm{de}$ & $0.0 \mathrm{~b}$ & $0.0 \mathrm{a}$ \\
\hline Untreated & & $0.0 \mathrm{a}$ & $0.0 \mathrm{e}$ & $0.0 \mathrm{~b}$ & $0.0 \mathrm{~d}$ \\
\hline Tukey's HSD $(p=0.10)$ & & 0.0 & 23.5 & 13.2 & 13.5 \\
\hline Standard Deviation & & 0.0 & 10.6 & 5.9 & 5.9 \\
\hline VC & & 0.0 & 21.8 & 8.0 & 7.2 \\
\hline
\end{tabular}

Values (mean \pm SE) followed by different letters are significantly $(\mathrm{p} \leq 0.10)$ different.

Table 4 - Visual injury on Triticum aestivum by Pyroxsulam, Braganey/PR/Brazil, 2011

\begin{tabular}{|c|c|c|c|c|c|}
\hline \multirow{2}{*}{ Name of treatment } & \multirow{2}{*}{$\begin{array}{c}\text { Rate } \\
\left(\mathrm{g} \text { a.i. } \mathrm{ha}^{-1}\right)\end{array}$} & \multicolumn{4}{|c|}{$\%$ Control } \\
\hline & & $7 \mathrm{DAA}$ & $14 \mathrm{DAA}$ & $28 \mathrm{DAA}$ & $45 \mathrm{DAA}$ \\
\hline Pyroxsulam & 15 & $0.0 \mathrm{a}$ & $0.0 \mathrm{a}$ & $0.0 \mathrm{a}$ & $0.0 \mathrm{a}$ \\
\hline Pyroxsulam & 18 & $0.0 \mathrm{a}$ & $0.0 \mathrm{a}$ & $0.0 \mathrm{a}$ & $0.0 \mathrm{a}$ \\
\hline Pyroxsulam & 21 & $0.0 \mathrm{a}$ & $0.0 \mathrm{a}$ & $0.0 \mathrm{a}$ & $0.0 \mathrm{a}$ \\
\hline Pyroxsulam & 30 & $0.0 \mathrm{a}$ & $0.0 \mathrm{a}$ & $0.0 \mathrm{a}$ & $0.0 \mathrm{a}$ \\
\hline Pyroxsulam & 36 & $1.0 \mathrm{a}$ & $1.0 \mathrm{a}$ & $0.0 \mathrm{a}$ & $0.0 \mathrm{a}$ \\
\hline Pyroxsulam & 42 & $1.0 \mathrm{a}$ & $1.0 \mathrm{a}$ & $0.0 \mathrm{a}$ & $0.0 \mathrm{a}$ \\
\hline Iodosulfuron & 5 & $0.0 \mathrm{a}$ & $0.0 \mathrm{a}$ & $0.0 \mathrm{a}$ & $0.0 \mathrm{a}$ \\
\hline Untreated & & $0.0 \mathrm{a}$ & $0.0 \mathrm{a}$ & $0.0 \mathrm{a}$ & $0.0 \mathrm{a}$ \\
\hline Tukey's HSD $(p=0.10)$ & & 1.6 & 0.5 & 0.0 & 0.0 \\
\hline Standard Deviation & & 0.2 & 0.5 & 0.0 & 0.0 \\
\hline $\mathrm{VC}$ & & 19.6 & 3.7 & 0.0 & 0.0 \\
\hline
\end{tabular}

Values (mean $\pm \mathrm{SE}$ ) followed by different letters are significantly $(\mathrm{p} \leq 0.10)$ different. 
slight visual injury $(<11 \%)$ to wheat at 14 DAA when applied at rates lower than $21 \mathrm{~g}$ a.i. ha ${ }^{-1}$. Rates 2-3 times higher and $42 \mathrm{~g}$ a.i. $\mathrm{ha}^{-1}$ )than the proposed label recommendation, caused up to $28 \%$ injury but the crop fully recovered from the injury by 45 DAA. The commercial rates (15 and $18 \mathrm{~g}$ a.i. $\mathrm{ha}^{-1}$ ) of pyroxsulam, at both locations, did not result in observable wheat injury at 28 DAA. Pyroxsylam at $18.4 \mathrm{~g}$ a.i. ha ${ }^{-1}$, caused 8 to $13 \%$ leaf injury at 14 DAA and injury symptoms disappeared and wheat recovered completely within 3 to 4 weeks (Reddy et al., 2013)

Pyroxsulam or iodosulfuron did not cause any significant reduction in wheat grain yield regardless of the rate applied (Table 5). Pyroxsulam applied at 15 or $18 \mathrm{~g}$ a.i. ha ${ }^{-1}$ provided excellent control of Lolium multiflorum while adversely effecting wheat response at two locations in Brazil.

Table 5 - Yield of Triticum aestivum at Cascavel and Braganey/PR/Brazil, 2011

\begin{tabular}{|c|c|c|c|}
\hline \multirow{2}{*}{ Name of treatment } & \multirow{2}{*}{$\begin{array}{c}\text { Rate } \\
\left(\mathrm{g} \mathrm{a} \text { a.i. } \mathrm{ha}^{-1}\right)\end{array}$} & \multicolumn{2}{|c|}{ Yield $\left(\mathrm{kg} \mathrm{ha}^{-1}\right)$} \\
\hline & & Branagey & Cascavel \\
\hline Pyroxsulam & 15 & $2269.0 \mathrm{a}$ & $1091.0 \mathrm{a}$ \\
\hline Pyroxsulam & 18 & $2493.0 \mathrm{a}$ & $1037.0 \mathrm{a}$ \\
\hline Pyroxsulam & 21 & $2058.0 \mathrm{a}$ & $874.0 \mathrm{a}$ \\
\hline Pyroxsulam & 30 & $1942.0 \mathrm{a}$ & $950.0 \mathrm{a}$ \\
\hline Pyroxsulam & 36 & $2558.0 \mathrm{a}$ & $1129.0 \mathrm{a}$ \\
\hline Pyroxsulam & 42 & $2308.0 \mathrm{a}$ & $1338.0 \mathrm{a}$ \\
\hline Iodosulfuron & 5 & $2375.0 \mathrm{a}$ & $1052.0 \mathrm{a}$ \\
\hline Untreated & & $1828.0 \mathrm{a}$ & $612.0 \mathrm{a}$ \\
\hline \multicolumn{2}{|l|}{ Tukey's HSD $(\mathrm{P}=.10)$} & 942.7 & 984.1 \\
\hline \multicolumn{2}{|l|}{ Standard Deviation } & 427.5 & 446.3 \\
\hline \multicolumn{2}{|l|}{$\mathrm{VC}$} & 18.3 & 44.2 \\
\hline
\end{tabular}

Values (mean $\pm \mathrm{SE}$ ) followed by different letters are significantly $(\mathrm{p} \leq 0.10)$ different.

\section{REFERENCES}

Buhler D.D. Weed population responses to weed control practices. I. Seed bank, weed populations, and crop yields. Weed Sci. 1999;47:416-22.

Companhia Nacional de Abastecimento - Conab. Acompanhamento da Safra Brasileira: graos, décimo levantamento. 2015. [acessado em: ago 8, 2017] Disponível em: http://www.conab.gov.br/conteudos.php?a=1253\&t=.

Deboer G.J., Thornburgh S., Ehr R.J. Uptake, translocation and metabolism of the herbicide florasulam in wheat and broadleaf weeds. Pest Manage Sci. 2006;62:316-24.

Devine M., Duke S.O., Fedtke C. Physiology of herbicide action. [s.1.]: PTR Prentice Hall, 1992.

Dow Agrosciences LLC. Pyroxsulam Technical Bulletin. Form No. Y45-356-001 (09/07) September, 2007. p.2-10.

Geier P.W. et al. Pyroxsulam compared with competitive standards for efficacy in winter wheat. Weed Technol. 2011;25:316-21.

Izquierdo J. et al. Effects of crop and weed densities on the interactions between barley and Lolium rigidum in several mediterranean locations. Agronomie. 2003;23:529-36.

Large E.C. Growth stages in cereals. Illustration of the Feekes scale. Plant Pathology. 1954;3:128-9.

Montazeri M., Zand E., Baghestani M.A. Weeds and their control in wheat fields of Iran. Adv Agron. 2005:58:57-93.

Nigro D. et al. Allelic variation of wheat flour allergens in a collection of wheat genotypes. J Chem. 2014;1:1-7.

Reddy S. et al. Downy brome (Bromus tectorum L.) and broadleaf weed control in winter wheat with acetolactate synthaseinhibiting herbicides. Agronomy. 2013;3:340-8 
Roman E.S. et al. Resistência de azevém (Lolium multiflorum) ao herbicida glyphosate. Planta Daninha. 2004;22:301-6.

Sociedade Brasileira da Ciência das Plantas Daninhas - SBCPD. Procedimentos para instalação, avaliação e análise de experimentos com herbicidas. Londrina: 1995. 42p.

Secretaría Estadual de Agricultura e Abastecimento do Estado do Paraná - SEAB. Faça sua Pesquisa. 2015. [acessado em: out. 6, 2015]. Disponível em: http://celepar07web.pr.gov.br/agrotoxicos/pesquisar.asp.

Vargas L. et al. Conyza bonariensis biotypes resistant to the glyphosate in southern Brazil. Planta Daninha. 2007;25:573-8.

Villegas M.C. et al. Período crítico de competencia de malezas en trigo (Triticum aestivum L.). Rev Mexic Cien Agr. 2004;30:223-34. 